\title{
Prospek Kerjasama Negara-Negara Asean dalam Pengendalian Pencemaran Udara Lintas Batas
}

\author{
M. Basarah
}

\begin{abstract}
Air pollution particularly in developing countries is not considered as a terrifying mater. The nuclear experiment in Brazil, For example, reminds us that all attempt to prevent air pollution should be made as soon as possible. The awareness of the developing countries about legal responsibility to commit various activities in their own countries does not cause air pollution and environmental defect; and it cannot be hesitated. The involvement of the developing countries in handling environmental matters is proof.
\end{abstract}

\section{Pendahuluan}

Pengertian tentang prospek erat kaitannya dengan persoalan masa depan. Dalam tulisan ini yang ingin dikemukakan adalah tentang apa kira-kira yang akan terjadi di kemudian hari jika syarat-syarat tertentu dapat dipenuhi.

Urutan permasalahan yang perlu mendapat perhatian agar tercapai suatu kesimpulan tentang apa yang akan terjadi di dalam pembahasan kerjasama antara negaranegara berkembang dalam hal pengendalian pencemaran udara, hampir tidak terbatas. Tetapi banyak urutan permasalahan yang akan dibahas, akan semakin pelik dalam membuat perencanaannya. Namun, dalam pembahasan tulisan ini yang akan dikemukakan hanya yang didasarkan pada

pertimbangan permasalahan-permasalahan atau indikator-indikator yang terbatas, dan lebih cenderung pada perkiraan.

Walaupun yang menjadi ide dasar tulisan ini, untuk mencari prospek kerjasama di antara negara-negara berkembang khususnya negara-negara anggota ASEAN. Namun karena permasalahan utamanya tentang cara pengendalian pencemaran udara lintas batas, maka perlu diketahui apa yang menyebabkan pencemaran udara tersebut. $\mathrm{Di}$ samping itu, yang perlu diketahui adalah apakah pencemaran udara lintas batas saat ini merupakan permasalahan bagi negaranegara berkembang? 
Akhir-akhir ini terdapat beberapa pendapat yang menekankan agar negara berkembang menghentikan tindakan untuk memproduksi minyak mentah, tapi digunakan di negara lain. ${ }^{1}$

$\mathrm{Hal}$ di atas dikemukakan berdasarkan fakta bahwa komoditi yang diolah siap pakai, nilainya lebih besar di pasar daripada memproduksi bahan mentah. Bahkan dapat menciptakan lapangan kerja lebih baik, terutama untuk meningkatkan tingkat perekonomian dan sosial negara bersangkutan. Demikian pula seharusnya yang dilakukan Indonesia yang, merupakan salah satu negara produsen minyak, bertindak seperti dikemukakan di atas, karena selain atas dasar pertimbangan tersebut penyaringan minyak mentah sesungguhnya merupakan salah satu sumber utama pencemaran udara.

Masalah pencemaran udara, seperti asap kebakaran hutan, emisi industri, mobil dan lain-lain yang sudah merupakan masalah nasional, secara internasional terutama masalah pencemaran udara yang diakibatkan kebakaran hutan di Sumatera dan Kalimantan baru dimulai. Hal ini terlihat dari perhatian yang begitu besar baik dari pemerintah Indonesia, Singapura maupun Malaysia, bahkan sekitar akhir bulan Oktober 1994 telah diadakan informal meeting wakil-wakil terkait ketiga negara tersebut yang khusus membahas masalah pencemaran udara. ${ }^{2}$ Hal tersebut tentu saja sangat menggembirakan karena merupakan masalah masa depan dalam batas-batas prospek kerjasama.

Dalam kaitannya dengan kondisi di atas, maka dalam pembahasannya perlu pula dikaji bagaimana persepsi hukum negara-negara berkembang tentang kondisi tersebut, dan sejauhmana prinsip yang dianut oleh negaranegara berkembang dalam pencegahan pencemaran udara lintas batas, terutama yang berasal dari wilayahnya sendiri. Seperti pemah. dikemukakan beberapa ahli hukum intemasional di Indonesia, perlunya harmonisasi hukum negara-negara berkembang khususnya di ASEAN. ${ }^{3}$ Untuk itu dalam hal ini perlu dikaji cara kerjasama yang perlu dilakukan dalam rangka pencegahan dan pengendalian pencemaran udara lintas batas.

Cara kerjasama tersebut dapat dimulai dalam lingkup ASEAN, misalnya atau mungkin kerjasama lembaga-lembaga ekstern dan mandiri yang tertarik dengan pencegahan dan pengendalian menurunnya lingkungan dan sumber daya alam.

\section{Penyebab Pencemaran Udara (Umum)}

Pembahasan tentang pencemaran udara tidak dapat terlepas dari pembahasan masalah lingkungan, bahkan pembahasan soal lingkungan akan lebịh luas. Karenạ di.

'Cees Flinterman, e.al. TRANSOUNDARY AIR POLUTION: Internatinal Legal Aspect of The Cooperation of States. Martinus Nijhoff. 1986. HIm. 241.

Dunia Dalam Berita TVRI tanggal 22 Oktober 1994.

${ }^{3}$ Khusus mengenai pembahasan perlunya kerjasama di bidang lingkungan hidup negara-negara ASEAN, lihat Daud Silalahi, Harmonisasi Hukum Negara-negara ASEAN di Bidang Lingkungan Hidup, Simposium Nasional Aspek-aspek Hukum Kerjasama Ekonomi Antara Negara-negaraASEAN dalam Rangka AFTA, Fakultas Hukum Universitas Padjadjaran 1993. 
dalam lingkungan tercakup semua sumber daya alam itu berada, faktor-faktor biokimia yang menciptakan interaksi alami dan eksistensi simbiotik antara sumber-sumber alam maupun struktur pisik yang disusun untuk memudahkan' pemukiman manusia. ${ }^{4}$ Dengan demikian, dapat dikatakan bahwa lingkungan merupakan gejala yang dapat mempersatukan; karena lingkungan terdiri dari banyak komponen yang meliputi inter alia flora, fauna, air, tanah dan manusia, yang masingmasing hidup dengan kekuatan biokimianya dan kelenturannya sendiri.

Oleh karena itu, pengertian lingkungan menunjukkan seluruh keragaman bendabenda, dengan tingkat resistensinya sendiri pada tekanan ekstern, tetapi semuanya saling berkaitan dan sering saling tergantung dengan cara menciptakan ekosistem. Hal tersebut berarti bahwa komponen-komponen lingkungan saling berkaitan dan saling ketergantungan, sehingga jika salah satu komponen tercemar dapat menyebabkan reaksi negatif yang mempengaruhi komponen-komponen lainnya. Berdasarkan kenyataan tersebut, maka usaha pengendalian lingkungan menjadi persoalan yang kompleks dan problematik. Usaha-usaha pengendalian lingkungan yang dilakukan oleh setiap negara berbeda-beda. Sejauhmana komponen yang satu dapat mempengaruhi komponen lain, sehingga menyebabkan menurunnya kualitas lingkungan.
Pencemaran udara dapat dalam bentuk asap, uap atau partikulat yang dibuang ke udara. Partikulat di udara dapat mencemarkan atau bahkan merusak udara, dan dapat menyebabkan masalah pernapasan dan jenisjenis penyakit lain pada manusia. Tetapi bagi semua komponen lainnya, dapat mengganggu dalam bentuk endapan kering atau hujan asam. Dari hasil penelitian terbukti, dengan dimasukkannya zat-zat kimia ke dalam. lingkungan, walaupun pada mulanya tidak nampak, tetapi dapat merusak lingkungan dalam jangka panjang. ${ }^{5}$ Oleh karena itu, terhadap pencemaran seperti ini, perlu penanganan hukum secara efektif.

Kedudukan hukum dalam pencemaran lingkungan adalah penting, sebagai bukti yang sangat meyakinkan terlihat dalam kasus besar the Smelter Case. ${ }^{6}$ Hakim Pengadilan Trail Smelter mengatakan, jika perumusan istilah pencemaran berdasarkan fakta-fakta pencemaran dapat ditentukan dengan cara, ex post facto, oleh bukti pencemaran yang telah terjadi. Maka hal ini akan berguna untuk dijadikan dasar dalam menentukan tanggung jawab negara yang melakukan pencemaran. Namun jika dasar ini dipergunakan, akan membatasi setiap rejim hukum yang akan dirancang untuk mencegah pencemaran yang akan terjadi. Dalam kaitan ini perlu dikemukakan bahwa tuntutan pencemaran harus didasarkan pada proses awal

${ }^{4}$ Cees Flinterman, et.al., Op. Cit., HIm. 236.

S/bid.

${ }^{6}$ Michel Preuer, 1991. Protection of the Environment, UNESCO: Martinus Nijhoff Pub. HIm. 1022. 
sebenarnya kenapa terjadi pencemaran, bukan didasarkan pada akibat terjadinya pencemaran.

Berdasarkan hal tersebut, beberapa ahli hukum mengemukakan, bahwa pencemaran didasarkan kepada proses awal suatu perubahan di dalam air, sehingga mengakibatkan kerusakan yang berarti. ${ }^{7}$ Dengan demikian,. proses awal suatu zat atau energi yang potensial merusak, dapat menyebabkan pencemaran.

Dari uraian di atas, tampak bahwa pengertian pencemaran tidak ditentukan oleh tingkat kerusakan yang disebabkan pencemaran. Pengertian kerusakan yang disebabkan pencemaran berguna untuk menentukan konsep pencemaran yang sebenamya, ex post facto, untuk menentukan dasar tanggung jawab. Tetapi hal tersebut tidak berguna untuk menentukan tujuan dalam menentukan suatu keadaan berdasarkan fakta-fakta yang pada hakekatnya akan berguna bagi rejim hukum yang bersifat preventif atau untuk mengatasi masalah di mana pelaku tidak dapat ditentukan atau di mana pencemaran dimulai karena sebabsebab alami. .

Penentuan standar khusus yang tergantung pada zat atau energi, nampak dalam kasus Nuclear Test yang diajukan kepada Mahkamah Internasional. ${ }^{8}$ Selain adanya keberatan dari pengadilan karena merasa tidak memiliki yurisdiksi dalam persoalan ini. Perancis juga berpendapat bahwa jika di dalam kenyataan terdapat pengendapan kebocoran radioaktif di wilayahwilayah Australia dan New Zealand jumlahnya sangat kecil, sehingga keluhan kedua negara tersebut tidak dapat dijamin.

Dalam hal ini, sesungguhnya pihak Australia dan New Zealand tidak berterus terang dengan adanya bukti orang-orang dan sumber-sumber alam lainnya yang terbunuh atau dirusak oleh kebocoran radioaktif tersebut. ${ }^{9}$ Tetapi, bagi kedua negara tersebut yang lebih penting adalah permohonan kepada pengadilan untuk menilai bahwa Nuclear Test di Pasifik Selatan bertentangan dengan hukum internasional, karena pengaruh kebocoran radioaktif di daerah tersebut pada umumnya dan wilayah kedua negara khususnya akan berbahaya bagi kesehatan teritorial. ${ }^{10}$

Tindakan-tindakan Perancis yang melakukan percobaan nuklir di wilayah Pasifik tersebut ternyata mendapat protes dari berbagai negara selain Australia dan New Zealand. Seperti Fij, Australia, dan Peru yang mengajukan permohonan ke pengadilan untuk memperoleh jawaban-jawaban Perancis agar dapat turut campur bersama-sama Australia dan New Zealand. Sementara Australia dan New Zealand dengan tiga negara lainnya, ${ }^{11}$

\footnotetext{
${ }^{7}$ Cees Flinterman, at.al. Op. Cit. HIm. 237.

'Lihat, Ian Brownlie. 1990. The Principles of Public Internasional Law, London: Clarendon Press, Him. 472-479.

${ }^{9}$ Cees F. Op. Cit'.

${ }^{10}$ Lihat, untuk hal ini pendapat Mahkamah Internasional, 6 dan 8 hakim menyetujuinya. Juga perhatikan mengenai hlm. ini pendapat tersendiri Hakim Forster. DJ. Harris. 1983. Case and Materials on Intemational Law. London: Sweet \& Maxwell, HIm. 734.

11 lbid.
} 
mencari peraturan-peraturan yang dapat menyatakan tindakan Perancis melanggar hukum internasional. Keadaan tersebut memperlihatkan bahwa pencemaran udara lintas batas merupakan permasalahan yang memerlukan pencegahan secepatnya. Oleh karena itu, dapat dikatakan bahwa pencemaran udara yang dipersoalkan dapat mempunyai arti regional, sebagaimana dinyatakan dalam protes negara-negara sepanjang samudra Pasifik.

Dari uraian di atas dapat dikemukakan halhal sebagai berikut, pertama, batasan pencemaran yang dapat memberikan jalan ke luar dari akibat-akibat yang mungkin ditimbulkan zat-zat yang digunakan secara umum, meskipun penentuan zat-zat dengan standar tertentu ditunda tetapi dapat dilaksanakan pada kasus tertentu; kedua, batasan-batasan pencemaran yang dapat mengantisipasi akibat-akibat pencemaran, mungkin sesuai dengan rejim hukum preventif. Tindakan pencegahan sesungguhnya dapat dilakukan sebelum timbulnya kerusakan walaupun pencemaran dapat saja terjadi; ketiga, batasan tersebut sangat cocok sebagai dasar kerjasama antar negara di dalam mengatasi pencemaran udara, tetapi bukan menentukan tanggung jawab atas kerusakan yang terjadi.

\section{Masalah Pencemaran Udara di Negara Berkembang}

Sebelum membahas lebih jauh, perlu terlebih dahulu mengidentifikasikan sumber- sumber pencemaran dan aktivitas-aktivitas yang menyebabkan pencemaran udara, terutama persepsi umum negara-negara berkembang terhadap masalah ini.

Salah satu sumber pencemaran udara yang paling berbahaya dan kontroversial adalah percobaan senjata nuklir di atmosfir: Karena penerapan percobaan senjata nuklir dapat menghancurkan kehidupan dan struktur-struktur pisik secara luas. Tetapi walaupun telah ditandatanganinya Nuclear Test Ban Treaty pada tahun 1963, ${ }^{12}$ Perancis dan Cina merupakan negara-negara yang menolak untuk mematuhi perjanjian tersebut. Bahkan Perancis terus melakukan percobaan atmosferiknya di kepulauan Pasifik yang sangat mengkhawatirkan negara-negara di daerah tersebut, yang mayoritas negaranegara berkembang.

Cina yang merupakan salah satu negara yang mengandalkan kekuatan nuklir, kurang lebih 20 tahun yang lalu telah melakukan 16 kali percobaan senjata nuklir, 15 di antaranya dilakukan di atmosfir. ${ }^{13}$ Dari percobaan tersebut yang dikhawatirkan adalah sifat kebocoran radioaktif. Sebagaimana dikemukakan oleh seorang politisi, bahwa jika pemerintah Perancis menganggap percobaan tersebut aman, seperti yang mereka kemukakan di pengadilan. Bagaimanapun akan ada sifat yang tidak terduga dari percobaan nuklir tersebut, dan bahaya serta kehancuran yang diakibatkan kebocoran memiliki potensi yang sangat besar untuk menghancurkan negara-negara berkembang, hal ini tentu saja menimbulkan protes banyak negara. ${ }^{14}$

12Lihat Notc. Nuclear Test Ban Treaties. BYIL No. 39/1963. HIm. 449-456.

${ }^{13}$ Cees F. Op. Cit. Hlm. 240.

${ }^{14}$ Lihat. Ian Brownlie. Supra. note 9. 
Sumber pencemaran udara, yang langsung berpengaruh terhadap lingkungan, adalah pencemaran udara yang diakibatkan oleh asap kebakaran hutan yang berlangsung lama. Pencemaran yang diakibatkan kebakaran hutan dapat mengakibatkan pencemaran udara lintas batas ke negara-negara terdekat daerah kebakaran. Dalam kaitan ini dapat dijadikan contoh peristiwa kebakaran hutan beberapa tahun yang lalu di daerah.Kalimantan dan Sumatera, yang mengakibatkan pencemaran lintas batas ke negara-negara lain seperti Singapura dan Malaysia. ${ }^{15}$ pencemaran udara tersebut mengundang perhatian pemerintah Singapura dan Malaysia: Karena selain menghambat jalur penerbangan rutin, dan menghambat perekonomian negaranegara tersebut juga dapat menimbulkan penyakit pernapasan.

Pencemaran udara yang ditimbulkan oleh pabrik. pencairan logam yang secara khusus terdapat dalam yurisprudensi adalah pencemaran, udara lintas batas yang ditimbulkan dari kasus Arbitrase Trail Smelter. Kasus tersebut:mempermasalahkan asap sulfur yang dikeluarkan oleh pabrik pencairan tembaga di Trail. Asap sulfur yang dikeluarkan pabrik pencairan logam Trail tersebut sebanyak 30 ton sehari, sehingga dalam sepuluh tahun jumlah asap sulfur sangat mengkhawatirkan dan menyebabkan penuntutan kepada badan arbitrase. ${ }^{16}$
Pentingnya contoh di atas, memperlihatkan tidak diperlukannya pabrik pencairan logam yang sangat besar, karena dapat menimbulkan pencemaran udara yang mengandung sulfur yang membahayakan kesehatan manusia. Walaupun hal tersebut tergantung dari kadar. sulfur yang dikeluarkan dari biji besi. Pabrik pencairan logam sebenarnya merupakan ciri yang menonjol dari negara maju (industri), tetapi dalam kaitan ini banyak negara berkembang yang perekonomiannya tergantung dari ekspor biji besi mentah, misalnya negaranegara Afrika.

- Selain pencemaran udara yang disebabkan pencairan logam, emisi industri umum saat ini sedang mendapat perhatian di beberapa negara, meskipun jumlah negara yang mengalami masalah ini sangat kecil: Seperti halnya Indonesia yang sedang mengembangkan perindustriannya baik kimia, pencairan logam, semen dan lain-lain, belum mempermasalahkannya (secara nasional) emisi yang ditimbulkan pabrik-pabrik industri tersebut. Padahal emisi yang dikeluarkan pabrik-pabrik industri, mobil dan kimia dapat merusak kesehatan. ${ }^{17 .}$ Contohnya Brazil yang mempunyai pusat industri di Cubatao yang berdekatan dengan Sao Paolo, yang dikenal dengan sebutan dengan Lembah Maut yang menimbulkan pencemaran yang sangat mengerikan (Death Valley is a Pollution Horror) dengan publisitas internasional yang luas sebagai salah satu daerah tercemar di dunia. ${ }^{18}$

15Lihat, Harian Umum Kompas 30 September dan 3 Oktober 1994.

${ }^{16}$ Dj. Harris. Op. Cit. Him. 205.

${ }^{17}$ Akibat pencemaran udara ini bencana yang merupakan kejadian nyata terjadi di Pensylvania AS pada tahun 1948, 20 orang meninggal dan ribuan menjadi sakit setelah inversi suhu yang terlalu lama sehingga meningkatkan polutan dari pabrik-pabrik baja dan pencair seng sampai tingkat yang membahayakan. B. Hileman. 1984. Formaldellyde: Assesing the Risk. Enviroment Science and Technology. New York. Him. 413.

${ }^{18} / \mathrm{bid}$. 
Karena di daerah ini terdapat penyaringan minyak tanah, pabrik-pabrik baja dan pabrik kimia yang mampu mengeluarkan 1000 ton polutan ke udara setiap hari.

Berdasarkan contoh di atas, apakah mungkin terdapat Cubatao lainnya di negara berkembang seperti di kawasan ASEAN, khususnya Indonesia? Pertanyaan ini memungkinkan untuk dikemukakan, karena pada kenyataannya jumlah pabrik-pabrik industri; baik industri kimia, tekstil, penyaringan minyak, semen dan lain-lain akan semakin meningkat keberadaannya di Indonesia.

Prediksi ini akan terbukti jika dikaitkan dengan keberadaan Undang-undang No. 1 Tahun 1967 tentang Penanaman Modal Asing dan dengan berbagai deregulasinya yang jelas akan banyak mengundang para "investor asing". Minat pengusaha asing jika tidak dihambat oleh situasi saat ini yang semakin buruk, tentu akan berbondong-bondong karena selain didukung oleh modal yang besar pemerintah mereka juga sangat mengharapkan pengusahanya hijrah ke negara lain. Seperti yang dilakukan oleh pemerintah AS, Jepang, Inggris, Perancis, Australia dan Kanada standar lingkungannya mereka sudah tinggi dalam arti tingkat pencemarannya sudah diambang batas, mereka berharap atau bahkan kemungkinan memaksa pengusahanya yang industrinya dianggap mengakibatkan pencemaran untuk mencari usaha ("perlindungan") di negara-negara berkembang yang standar dan infrastrukturnya belum maju.
Adanya kenyataan yang menunjukkan sikap yang meluas dari negara-negara berkembang yang menganggap bahwa pencemaran merupakan bagian dari keadaan-keadaan yang menyebabkan kemakmuran ekonomi negara-negara maju, seperti Amerika Serikat, Eropa dan Jepang, adalah merupakan pandangan yang keliru, karena dengan pandangan demikian berarti pembangunan ekonomi tidak relevan dengan peraturan lingkungan. ${ }^{19}$ Meskipun sebagian negara-negara berkembang menunjukkan kemakmuran ekonominya oleh jumlah industri yang didirikan di dalamnya, bukan berarti bahwa pemilik industri-industri besar tersebut merupakan milik perusahaan nasionalnya. Mereka tidak menyadari bahwa pemilik industri-industri besar tersebut sebagian besar milik perusahaan multinasionat asing.

Oleh karena itu, sumber-sumber alam yang dibutuhkan untuk menunjang pembangunan di negara-negara berkembang, seperti hutan, tanaman dan vegetasi dapat dirusak oleh udara industri yang semakin berkembang. Demikian pula air bersih dan aman yang sangat dibutuhkan akan semakin menipis. Adanya produk industri makanan seperti ikan, daging dan makanan lainnya yang masih dibutuhkan di dalam negerinya tentunya akan berkurang dan rusak.

Berdasarkan pengamatan di atas, dapat diperkirakan bahwa banyaknya jumlah industri tidak dapat menjamin kehidupan yang nyaman dan aman. Oleh karena itu, yang penting bagi

19Lihat mengenai konsep pembangunan berkelanjutan dan berwawasan lingkungan, Daud Silalahi, Perangkat Hukum Nasional, Regional dan Internasional yang Berkelanjutan, dalam Jumal Hukum Lingkungan No. 1 Tahun. 1993. HIm. 32 dst. 
negara berkembang pelaksanaan pembangunannya harus mengikuti konsep pembangunan yang berwawasan lingkungan, baik secara nasional maupun internasional. ${ }^{20}$

Konsep pembangunan yang berwawasan lingkungan yang merupakan salah satu'pokok bahasan dalam Konperensi PBB tentang Lingkungan Hidup tahun 1972, sesungguhnya tidak mengurangi nilai industrialisasi dalam pembangunan. Karena konsep ini menekankan pada nilai perencanaan nasional. yang seimbang dengan melindungi kekayaan milik negara secara terpadu, dan tidak dirusak oleh industri. Gagasan tersebut sesungguhnya telah dirumuskan secara kongkrit oleh Pemerintah Indonesia dalam REPELITA II: tahun 1974. Tentunya kita menganggap bahwa konsep tersebut dapat menunjang pembangunan di negara-negara berkembang, karena jika tidak demikian sangat ironis jika terjadinya pencemaran di suatu negara karena akibat pencemaran yang ditimbulkan negara lain.

\section{Prospek Kerjasama Negara-negara Asean dalam Pengendalian Pencemaran Udara Lintas Batas}

Upaya pengendalian pencemaran lingkungan sesungguhnya telah dianut dalam perundang-undangan penanaman modal asing negara-negara ASEAN. Bahkan dalam program dan kegiatan UNEP sejak pembentukannya terutama ditujukan untuk mendorong kerjasama regional, termasuk membentuk perjanjian dan kesepakatan regional, terdapat keseragaman landasan hukum ditiap region, seperti ASEAN. ${ }^{21}$ Dalam hal kerjasama tersebut, yang perlu diperhatikan selain program UNEP adalah keinginari prinsip-prinsip 21, 22, dan 24 dari Deklarasi Stockholm 1972. Prinsip 21 menyatakan:

States have, in accordance with the Charter of the United Nations and the priciples of international law, the soverign right to exploit their own resources pursuant to their own environmental policies, and the responsibility to ensure that activities within their jurisdiction or control do not cause damage to the environment of other States or of areas beyond the limits of national jurisdiction.

Ketentuan tersebut tampaknya merupakan petunjuk bagaimana menghormati kepentingan negara lain, dan hak-hak negara lain yang dilindungi oleh hukum. Selain itu, perlu dikemukakan bahwa ruang lingkup prinsip ini meliputi juga yurisdiksi laut lepas, ruang udara dan ruang angkasa. ${ }^{22}$ Tetapi yang penting dalam hal ini, negara-negara berkembang menerima tanggung jawab bahwa aktivitas-aktivitas di wilayahnya tidak akan menyebabkan kerusakan lingkungan di luar batas-batas yurisdiksi nasionalnya.

2o Lihat. Ibid.

${ }^{21}$ Daud Silalahi, Harmonisasi Hukum... Op. Cit., HIm. 2.

22L.B. Sohn. "The Stockholm Declaration on the Human Environment", Harvard International Law Journal No. 14/1973. HIm. 423. 
Tanggung jawab negara terhadap kerusakan lingkungan yang mewajibkan negara-negara untuk menerimanya, diatur secara khusus dalam prinsip 22 yang menyatakan:

States shall co-operate to develop further the intemational law regarding liability and compensation for the victims of pollution and other environmental damage caused by activities within the jurisdiction or control of such States to areas beyond their jurisdiction.

Prinsip ini secara efektif mendorong negara-negara untuk bekerjasama dalam mengembangkan hukum internásional, tidak sebatas dalam hal tanggung jawab saja. Karena yang terpenting dalam pengelolaan lingkungan bukan akibatnya, tetapi pencegahan. Namun dalam hal tanggung jawab terhadap kerusakan lingkungan, telah ada kasus dalam hukum internașional yang menunjukkan diterimanya masalah tanggung jawab ini, yaitu kasus Showa Maru dan Arbitral Smelter Case.

Prinsip lainnya adalah Prinsip 24 yang berisi keinginan terjalinnya kerjasama internasional secara damai dalam masalah lingkungan dan mendorong terjalinnya kerjasama multilateral dan bilateral:

Intemational matters concerning protection and improvment of the environment should be handled in a co-operative spirit by all countries, big or small, on equal footing. Co-operation throught multirateral or bilateral arrangement or other appropriate means is essential to efectively control, prevent, reduce and elimanate adverse effects resulting from activities conducted in all spheres, in such a way that due account is taken of soverignty and interests of all States.

Dalam kaitannya dengan prinsip di sini kerjasama yang harus segera direalisasikan oleh negara-negara ASEAN adalah kerjasama dalam pengendalian, dan pencegahan pencemaran udara. Salah satu indikasi yang akhir-akhir menjadi masalah yang sangat kompleks, dan dapat mendorong ke arah terwujudnya kerjasama yaitu pencemaran udara yang ditimbulkan kebakaran hutan di daerah Sumatera dan Kalimantan. Asap yang ditimbulkan akibat kebakaran tersebut telah mencemarkan lingkungan di daerah terdekat terutama Singapua dan Malaysia.

Walaupun untuk mewujudkan kerjasama pengendalian pencemaran udara tersebut tidak terlepas dari masalah-masalah hukum, sistem nilai, politik, ekonomi dan budaya. ${ }^{23}$ Dalam kerjasama ini karena merupakan rintisan kerjasama dalam salah satu aspek pencemaran lingkungan, sebaiknya yang menjadi acuan pembahasan adalah hasil kerjasamanya atau rintisan yang telah dilakukan sebelumnya, misalnya, seperti yang tercermin dalam Deklarasi Manila tahun 1981. Seperti dikemukakan dalam Resolusi Majelis Umum PBB 3129 (XXVIII) paragrap 83 menyatakan:

In a situation where the likelihood of damage to the environment of other States from the unilateral actions of a co-sharing State to great, the issue is not how to compen-

${ }^{23}$ Lihat. Daud Silalahi. Op. Cit. HIm. 5-7. 
sate for that damage, but rather how to pre. vent the damage from occuring in the first place, without infringing the soverignty of the State concerned or derogating from its soverign rights over natural resources within it jurisdiction or control: What is needed therefore, is a system of co-operation that would harmonize the action of the States concerned and protect their environment.

Dengan demikian jelas, bahwa Resolusi PBB tersebut tidak menginginkan bentuk kerjasama yang kaku, bahkan bentuk kerjasama dimaksud dapat dilakukan dalam hal-hal teknis. Karena Resolusi tersebut lebih menekankan adanya kerjasama dalam pengendalian pencemaran, bukan menentukan ukuran tanggung jawab suatu negara yang melakukan pencemaran.

Dalam rangka kerjasama negara-negara berkembang khususnya negara-negara ASEAN di bidang pencemaran udara, yang perlu mendapat perhatian adalah kertas kerja Indonesia dalam menghadapi Konvensi Montevideo untuk melaksanakan Decision $8 /$ 15 dan Decision 9/19 yang dilaksanakan dalam Sidang Negara-negara berkembang. ${ }^{24}$ Kerja pertama yang berjudul Marine Pollution Control and Prevention Throught Regional Arrangements in South-East Asia memberikan gambaran yang jelas tentang perkembangan dan semangat regionalisme dan pengalaman tata pengaturan regional di Asia Tenggara.
Gambaran sumbangan pikiran Indonesia tersebut dengan jelas dapat dikemukakan sebagai berikut: ${ }^{25}$ (a) pengertian dan kesadaran negara berkembang tentang Hukum Lingkungan yang sedang tumbuh; (b) cita-cita dan aspirasi negara berkembang untuk turut serta mengembangkan Hukum Lingkungan; (c) rintisan upaya negara berkembang dalam membangun Hukum Lingkungan; (d) kesulitan dan hambatanhambatan yang dihadapi oleh negara-negara berkembang dalam upaya tersebut; (e) garis kebijaksanaan pembangunan" Hukum Lingkungan secara nasional; (f) 'peningkatan upaya nasional ke taraf bilateral; (g) pemekaran upaya bilateral kepada tata pengaturan subregional tri-negara; dan (h) pengembangan upaya subregional ketingkat tata pengaturan regional panca-negara ASEAN; (i) pembulatan tata pengaturan regional menjadi kerjasama regional secara utuh menyeluruḥ; dan (j) upaya penyerasian kerjasama regional (ASEAN) dengan kepentingan global.

Uraian kertas kerja yang disajikan Indonesia tersebut memperihatkan satu kesatuan bulat dalam konsepsi serta penjabarannya yang terinci, dan akan sangat bermanfaat bagi sidang-sidang maupun rencana kerjasama di bidang pengendalian pencemaran lainnya di masa yang akan datang. Bahkan kertas kerja tersebut telah menjawab hampir semua pertanyaan dan persoalan yang ditampilkan dalam Decision 8/15 dan Decision 9/19

${ }^{24}$ Lihat. ST. Munadjat Danusaputro. 1982. Hukum Lingkungan: Buku III Regional, Bandung: Binacipta. HIm. 234-236.

${ }^{25} / \mathrm{bid}$. 
tersebut. Oleh karena itu, tidak ada salahnya jika kerangka yang disajikan dalam kertas kerja tersebut dijadikan sebagai dasar kerjasama negara-negara ASEAN dalam bidang pencemaran udara. Karena sebagai negara yang menuju negara industri, masalah pencemaran udara lintas batas yang akan timbul perlu mendapat perhatian khusus.

Di samping kertas kerja tersebut, yang dapat dijadikan dasar kerjasama negaranegara ASEAN dalam pencemaran udara adalah Konsep Dasar (Basic Concept) yang disumbangkan Indonesia dalam Sidang Negara-negara Berkembang tanggal 7-8 September 1981. Rumusan. konsep dasar tersebut, sebagai berikut: ${ }^{26}$.

1. Hukum adalah sarana pokok untuk pengelolaan lingkungan hidup berikut sumber dayanya secara sehat, sedang - pembangunan dan penerapannya berarti sangat penting bagi semua bangsa. Pembangunan dan penerapan Hukum Lingkungan harus dikembangkan dengan memperhatikan terutama sekali keadaan dan kebutuhan khusus dari negaranegara berkembang.

2. Bagi negara-negara berkembang kesulitan terpokok dalam menguraikan dan menerapkan penyelesaian hukum secara efektif terhadap masalah-masalah lingkungan terletak antara lain dalam kesukaran karena tidak tersedianya secara cukup informasi dan partisipasi masyarakat, prasarana, tenaga manusia, teknologi dan sumber keuangan guna menjamin pelaksanaannya. Oleh karena itu, kerjasama internasional dan terutama bantuan teknis seharusnya dikembangkan untuk tujuan dimaksud.

3. Juga terasa perlunya agar negara-negara berkembang menyerasikan pertimbangan pembangunan dengan kepentingan lingkungan melalui penerapan tata pendekatan terpadu dan terkoordinasi pada semua tingkatan, terutama pada permulaan perundang-undangan lingkungan dan penerapannya. Pemerintah negara-negara maju seharusnya memberikan bantuan dalam pengembangan dan administrasi hukum serta peraturan-peraturan yang dibuat untuk menghindari resiko lingkungan yang bertalian dengan teknologi.

Konsep dasar di atas jelas dapat berguna dan bermanfaat bagi negara-negara berkembang, karena dapat digunakan dalam lingkungan nasionalnya. Bahkan dalam sidang terungkap adanya keinginan konsep dasar ini dimasukkan ke dalam rumusan Pola Pembangunan Hukum Lingkungan Sedunia. Berdasarkan kenyataan tersebut, kiranya tidak perlu diragukan lagi terutama bagi negaranegara berkembang khususnya negaranegara ASEAN dua konsep dasar di atas dapat dijadikan pola kerjasama bidang lingkungan hidup khususnya pencemaran udara di masa mendatang.

\section{Simpulan}

Dari uraian di atas dapat disimpulkan halhal sebagai berikut bahwa pencemaran udara

${ }^{26} /$ bid. 
walaupun bukan merupakan masalah yang menakutkan, terutama di negara-negara berkembang. Contoh kasús seperti percobaan nuklir, peristiwa Brazil sangat berguna untuk dijadikan sebagai peringatan bahwa segala' macam usaha untuk mencegah pencemaran udara harus secepatnya dilakukan.Kesadaran negara-negara berkembang terhadap. tanggung jawab hukum dari kegiatan yang di dalam wilayahnya, untuk tidak mengganggi " atau merusak lingkungan negara lain, tidak perlu diragukanlagi. Hal ini térbukti dengan terlibatnya negara-negara tersebut dalam masalah lingkungan.

Perlu diakui bahwa untuk mènjalin kerjasama secara hukum di negara-negara berkembang terdapat beberapa prinsip agar kerjàsamä dilaksanakan penuh kedamaian yang dapat dijadikan pétunjuk dan jika sesuai dapat diaplikasikan ke dalam perjanjian formal. Prospek kerjasama negara-negara berkembang khususnya negara- negara ASEAN di dalam mencegah pencemaran udara lintas batas, dapat mengacu pada konsep dasar yang'sudah ada dan sudah diterima oleh negára-negara berkembang lainnya:-Yang mungkin konsep ini terlupakan, séhinggà diperlukàn-lagi pertemuan-pertemuan yang dapat mementahkan konsep tersebut.

\section{Daftar Pustaka}

Brownlie, 'lan: 1990. Principles of Public International Law. London: Clarendon Press.

Flinterman, Cees. et.al. 1986. Transboundary Air Pollution: International Legal Aspect of the Co-operation of States. Martinus Nijhoff.
Hileman, B. .1984, Formaldelhyde: Assesyng the Risk Environment Science and Technology. New York.

Harris, D.J. 1983.Case and Materials on International Law. Sweet \& Maxwell, London,

Preuer; Michel, 1991.Protection of The En-. vironment, Martinus Nijhoff UNESCO,

St. Munadjat Danusaputro, 1982. Hukum "Lingkungan : Buku III Régional, Bina Cipta, Bandung,

' Artikel-artikel:'

Daud Silàlahi, Perangkat Hựkúm Nasional, Regional dan Internasional yang Berkelanjutan, Jurnal Hukum? Lingkungan No. 1 tahùn 1993.

Daud Silalahi, Harmonisasi Huküm Negaranegara ASEAN di Bidang Lingkungan Hidup, Simposium Nasional: Aspek-aspek ...Hukum Kerjasama Ekonomi antara Negaranégara ASEAN dalam Rangka AFTA, UNPAD 1983.

Notc, Nuclear Test Ban Treaties, B.Y.I.L No: 39/1963.

Sohn, L.B., The Stockholm Declaration on the Human Environment, Harvard In: temational Law Journal 'No.' 14/1973.

Dokumen-dokumen:

Stockholm Declaration on the Human Environment 1972.

Res. PBB 3129 (XXVIII).

Harian Umum Kompas. 